\title{
Kinesiophobia Following Anterior Cruciate Ligament Reconstruction
}

\author{
Ön Çapraz Bağ Rekonstrüksiyonu Yapılan Hastalarda Kinezyofobi
}

\author{
Alauddin Kochai ${ }^{1}$, Levent Bayam ${ }^{1}$, Mehmet Erdem ${ }^{1}$, Ahmet Can Erdem ${ }^{2}$, \\ Deniz Gülabi ${ }^{3}$, Uğur Özdemir ${ }^{1}$, Ünal Erkorkmaz ${ }^{4}$ \\ ${ }^{1}$ Sakarya Üniversitesi Tip Fakültesi, Sakarya, Ortopedi ve travmatoloji Ana-bilim dalı. Sakarya/Türkiye \\ ${ }^{2}$ Bezmialem Üniversitesi, Tip Fakültesi, Ortopedi ve travmatoloji Anabilim dal. İstanbul / Türkiye \\ ${ }^{3}$ Lütfi Kırdar Kartal Training and Research Hospital, Ortopedi ve travmatoloji Anabilim dall. Kartal, İstanbul 34890, Turkey \\ ${ }^{4}$ Sakarya Üniversitesi, Tip Fakültesi, Biyoistatistik Anabilim Dalı Sakarya / Türkiye
}

\author{
Yazış̧ma Adresi / Correspondence: \\ Alauddin Kochai \\ MD, Consultant Orthopaedic Surgeon. Sakarya University faculty of medicine, Orthopaedic and Traumatology Department, Sakarya, Turkey
}

T: +90532 3275562 E-mail: alkoc79@gmail.com12

Geliș Tarihi / Received : 12.04.2019 Kabul Tarihi / Accepted : 21.06.2019

Orcid No:

Alauddin Kochai https://orcid.org/0000-0002-5775-102X

Levent Bayam https://orcid.org/0000-0001-5149-0829

Mehmet Erdem https://orcid.org/0000-0002-9683-1882

Ahmet Can Erdem https://orcid.org/0000-0002-4763-1112

Deniz Gülabi https://orcid.org/0000-0002-4131-7536

Uğur Özdemir https://orcid.org/0000-0003-2889-8118

Ünal Erkorkmaz https://orcid.org/0000-0002-8497-4704

\footnotetext{
Abstract

Objective The aim of the study was to explore the effect of kinesiophobia on daily and sport activities of the patients following their anterior cruciate ligament (ACL) reconstruction. We correlated Tampa scale of Kinesiophobia (TSK) with Tagner Activity score (TAS). We hypothesized that high level of Tam-pa scale of Kinesiophobia decreases Tagner Activity score. ( Sakarya Med J 2019, 9(2):289-296 )

Materials A total of 50 patients, who had Anterior cruciate ligament (ACL) reconstruction surgery between January 2010 and December 2016 were included to this study. KT-1000 and Methods arthrometer at 30 de-grees knee flexion was performed for both knees. Patients completed Lysholm Knee, TAS and TSK questionnaires postoperatively and TSK score was correlated with TAS and Lysholm knee score

Results Mean age was 29.6 (18-50) and minimum follow-up was 12 months. Twenty out of 50 patients (\%40) had meniscal tears. There was significant and inverse correlation between TAS and TSK. Higher TSK led to lower TAS whilst lower TSK led to higher TAS. However, there was no correla-tion between Lysholm knee score, TAS and TKS in patients with or without meniscal tear.

Conclusion Our study showed that good knee function is not the only indicator to return preinjury daily and sport activities but kinesiophobia may also play a significant role even if Lyshman knee score is higher. Therefore, the patients with ACL injury should be informed about the kinesiophobia. We suggest that a kinesiophobia test could be added to the patients assessments with ACL injury. The patients who have high rate of kinesiophobia preoperatively, may benefit from psychotherapy postoperatively in addition to their physical therapy.

Keywords Anterior Cruciate Ligament; Kinesiophobia; Lysholm knee score; Meniscal tear
}

Amaç Kinezyofobinin gündelik ve sportif aktivitelerin üzerindeki rolünü, Tempa Kinezyofobi skorunu (TSK) Tagner aktivite skoru (TAS) ile karșılaștırarak araștırmayı amaçladık. Hipotez: Yüksek Tempa Kinezyofobi skoru Tagner aktivite skorunu düşürür. ( Sakarya Tip Dergisi 2019, 9(2):289-296).

Gereç ve Ocak 2010-Aralı 2016 yılları arasında ön çapraz bağ rekonstrüksiyonu yapılan 50 hasta çalışma-ya dahil edildi. Tüm hastalara Lysholm diz skorlaması, Tagner aktivite skorlaması ve Yöntemler Tempa Kinezyofobi skorlamast uyguland. Hastalarn her iki dizine 30 derecede KT-1000 artrometre uygu-landı. Tempa Kinezyofobi skoru, Tagner aktivite skoru ve Lysholm knee skoru ile karșilaștırldt.

Bulgular Hastaların ortalama yaș 29.6(18-50) ve minimum takip süreleri 12 ay idi. Hastaların 20’sinde (\%40) aynı zamanda menisküs yırtı̆̆ı mevcuttu. Tagner aktivite skoru, Tempa Kinezyofobi skoru ile karşılaștrrldı̆̆ında anlamlı ve ters yönde bir korelasyon olduğu görüldü. Yüksek Tempa kinezyofobi skoru olan hastalarda Tegner aktivite skoru düşük; düşük Tempa kinezyofobi skoru olan hastalarda Tegner aktivite skoru anlamlı olarak yüksek olduğu görüldü. İstatistiksel olarak TKS, TAS, Lysholm skorları ve menisküs yırtı̆̆ı olan ve olmayan hastalar arasında anlamle bir fark bulunamadi.

Sonuc Calısmamız, diz fonksiyonlarının yaralanma öncesi gündelik aktivite ve sportif aktiviteye geri dönüs için tek bașına yeterli olmadığın gösterdi. Lysholm skoru yüksek olsa bile kinezyofobinin hasta-ların gündelik ve sportif aktivitelerine geri dönüşlerinde negatif bir rol oynadı̆̆ı görüldü. Çalışmamızın sonuçlarına göre, tüm ön çapraz bağ yırtı̆̆ için opere edilecek hastalarda, kinezyo-fobi hakknda ameliyattan önce bilgilendirilmesi ve kinezyofobi testi yapılmasi tavsiye edilir. Yüksek kinezyofobi skoru olan hastalar, ameliyat sonrası fizik tedavinin yanında psikoterapiden de fayda-lanabilirler. 


\section{INTRODUCTION}

Anterior cruciate ligament (ACL) rupture is a common injury in professional and amateur athletes. ${ }^{1}$ ACL rupture frequently causes disability in athletes and usually occurs during sport activities fol-lowing sudden turning, jumping, or pivoting movement. ${ }^{2,3}$ The standard surgical treatment of ACL rupture is reconstruction of the ligament. It stabilises the knee joint and helps preventing further injuries and returning to previous levels of activity. ${ }^{4}$ After surgery, rehabilitation aids to restore range of motion, strength, movement control, and knee function. ${ }^{5}$ During rehabilitation, not only physical but also psychological factors could be indicators of success in outcome. However, only $65 \%$ of patients return to their preinjury level or sportive activity after anterior cruciate ligament reconstruction. ${ }^{6,7}$

Kinesiophobia is fear of movement or fear of re-injury after or before operation. It is also the most extreme form of fear of movement and is defined as irrational and debilitating fear of physical movement or activity resulting from a feeling of vulnerability to painful reinjury. ${ }^{8}$ The Cognitive Fear Avoidance Model describes this as when a painful experience is interpreted as threatening, it can generate catastrophizing (or catastrophic) cognitions in a way that the activity will result in more pain and re-injury. As this goes on, it can lead to avoidance behavior, which in the long run, causes disability, disuse and depression as well as patient feeling trapped in a cycle of increased fear of pain, more pain and disability. ${ }^{9}$ In recent years, the integration of the biopsychosocial model in rehabilitation has been receiving attention in clinical research. Implementing psychologi-cal factors assessment and management in rehabilitation for patients with musculoskeletal inju-ries/ pain can aid in the decision-making process and improve outcomes. Therefore, it is important to know which psychological factors are related to the rehabilitation process and can contribute to a good recovery. The psychological influences such as self-efficacy, confidence in function, catastrophizing pain, kinesiophobia or reinjury may modulate individual perception and response to the illness, and may influence functional level after musculoskeletal injury. ${ }^{10,11,12}$ These fears can decrease daily activities and sportive success.

In this study, we aimed to explore the effect of kinesiophobia on daily and sport activities of the patients following their anterior cruciate ligament (ACL) reconstruction. We correlated Tampa scale of Kinesiophobia (TSK) with Tagner Activity score(TAS). We hypothesized that high level of TSK decreases TAS but may or may not be correlated with Lysholm knee score(LKS).

\section{MATERIALS and METHODS}

A total of 61 patients were evaluated who were surgically treated with ACL reconstruction surgery according to the data from our medical records of the patients. We did not exclude the patients with additional meniscal tears. Inclusion criteria were the patients aged between 16-50 years who underwent elective, primary ACL reconstruction with hamstring autogenous graft between January 2010 and December 2016. Exclusion criteria were previous surgery on the ipsilateral knee, multi-ligamentous reconstruction, concomitant bony procedure and the patients who were unwilling to undergo evaluation. To identify the accurate rate of kinesiophobia, we also excluded the patients with revision ACL surgery. All the surgical procedure of the patients included to this study were performed by the same surgeon. A total of 50 patients were included to the study after excluding 6 patients due to revision and 5 patients due to multi-ligament reconstruction. All the patients underwent an arthroscopic ACL reconstruction with double-looped autogenous semitendinosus and gracilis tendons. All grafts were fixed with close-looped Endobutton ${ }^{\circ}$ (Smith \& Nephew) proximally. On the tibial side, all the grafts were fixed with staples (Smith \& Nephew) and interference screws (Smith \& Nephew). Meniscal tears were repaired with inside-outside technique.

Postoperatively, all patients underwent physiotherapy with the same protocol. Patients with ACL reconstruction were 
allowed full weight bearing but patients with additional meniscal repair kept on non-weight bearing status for 4 weeks and after then, they started full weight bearing on the op-erated side. All the patients had a knee brace applied on the operated limb in the beginning and allowed 0 to 90 range of motion.

The patients completed Lysholm Knee, Tegner activity score and TSK questionnaires postopera-tively. Both knees of the patients (operated and unoperated sides) were assessed with KT-1000 arthrometer at 30 degrees knee flexion. The differences of anterior shifts between the knees were calculated using metric system (in millimetres).

Kinesiophobia was measured using a 17 -item version of Tampa Scale of Kinesiophobia (TSK-17). In the 17 items of the scale, each item had 4 response options; all anchored with the answers from "strongly disagree", which scores 1 point to "strongly agree", which scores 4 points. The total sum score is calculated and can range between 17 and 68 points. Vlaeyen et al. defined a cut-off of $>37$ as showing a high degree of kinesiophobia.6 A high score indicates strong fear of move-ment / (re)injury. The Lysholm knee score is a measure of knee function, symptoms and disability. It consists of 8 components related to knee function on a 100-point scale. Tegner activity score measures a person's activity level and it is numbered between 0 and 10 , where 0 is 'on sick leave/disability' and 10 is 'participation in competitive sports such as soccer at a nation-al or international elite level.

This research has been approved by the IRB of the authors' affiliated institutions (Sakarya Univer-sity). (Number: 71522473/050.01.04/183. Date: 02.07.2018)

This study is a cross-sectional type research.

\section{Statistical Analysis}

Descriptive analyses were performed to provide information on general characteristics of the study population.
Kolmogorov-Smirnov test was used to evaluate whether the distribution of numeric variables were normal. Accordingly, it was seen that all scales displayed a normal distribution. Therefore, two independent sample t test was used to compare the numeric variables between two groups. The numeric variables were presented as the mean \pm standart deviation. Categorical variables were compared by Chi-Square test. Categorical variables were presented as a count and percentage. Pearson correlation coefficient was performed for relation between Lysholm knee score (LKS) and Tampa scale of Kinesiophobia (TSK) and with Tagner Activity score (TAS). A p-value $<0.05$ was considered statistically significant. Analyses were performed using SPSS statisti-cal software (IBM SPSS Statistics, Version 23.0. Armonk, NY: IBM Corp.)

\section{RESULTS}

This study was performed on 50 subjects among the age group between 18 to 50 years (mean age was 29.6). All the patients were male. Minimum follow-up was 12 months after primary ACL reconstruction and the mean follow up was 34.18 months (12-60). Twenty out of 50 patients (\%40) had meniscal tears and all were repaired with inside - out technique. Fifteen of them were for medial meniscus and 5 were for lateral meniscus tears (Table 1).

The mean Tegner activity score was 6.76(0-10). The mean Lysholm knee and postoperative Tam-pa Kinesiophobia scores were 92.3 (85-100) and 35.8 (20-64) respectively. There was no differ-ence in the mean of anterior translation of the knees (operated and un-operated) using the KT-1000 arthrometer side-to-side. There was no difference when correlating Lysholm scores to TSK score. For the patients with additional meniscal tear, the mean Tegner activity score for meniscal tear patients was 5.85(0-10). Again, the mean Lysholm knee and postoperative Tampa Kinesio-phobia scores were 90.25(85-100) and 42.1 (2064). Similarly, there was no difference in Lysholm score compared to TSK score in patient with or without meniscal tear. Also, there was no differ-ence in TAS in the patient 
Sakarya Med J 2019;9(2):289-296

KOCHAI et al. Kinesiophobia Following ACL

Table 1. Distrubutions of socio-demographic and treatment characteristics of groups

\begin{tabular}{|c|c|c|c|c|c|}
\hline & & $\begin{array}{l}\text { Total } \\
(\mathbf{n}=50)\end{array}$ & $\begin{array}{c}\text { Non-Meniscal Tear } \\
(\mathbf{n}=\mathbf{3 0})\end{array}$ & $\begin{array}{c}\text { Meniscal Tears } \\
(\mathbf{n}=\mathbf{2 0})\end{array}$ & $\mathbf{p}$ \\
\hline \multirow{2}{*}{ Side } & Right & $36(72)$ & $22(73.3)$ & $14(70)$ & \multirow{2}{*}{1.000} \\
\hline & Left & $14(28)$ & $8(26.7)$ & $6(30)$ & \\
\hline \multirow{2}{*}{ Cigarette } & User & $34(68)$ & $21(70.0)$ & $13(65.0)$ & \multirow{2}{*}{0.951} \\
\hline & Non-user & $16(32)$ & $9(30.0)$ & $7(35.0)$ & \\
\hline \multirow{2}{*}{ Complica-tion } & Negative & $49(98)$ & $29(96.7)$ & $20(100)$ & \multirow{2}{*}{1.000} \\
\hline & Positive & $1(2)$ & $1(3.3)$ & 0 & \\
\hline \multirow{3}{*}{$\begin{array}{l}\text { Meniscal tear } \\
\text { Treatment }\end{array}$} & Lateral Meniscal tear & $5(25)$ & & $5(25)$ & \\
\hline & Medial meniscal tear & $15(75)$ & & $15(75)$ & \\
\hline & Inside- Outside & $20(100)$ & & $20(100)$ & \\
\hline \multicolumn{2}{|l|}{ Age } & $29,32 \pm 9,63$ & $27.07 \pm 9.13$ & $32.7 \pm 9.58$ & 0.041 \\
\hline \multicolumn{2}{|c|}{ BMI ( Body Mass Index) } & $27,44 \pm 3,58$ & $27.27 \pm 2.65$ & $27.7 \pm 4.71$ & 0.680 \\
\hline \multicolumn{2}{|l|}{ Follow-up } & $34,18 \pm 12,52$ & $34.17 \pm 12.37$ & $34.2 \pm 13.07$ & 0.993 \\
\hline
\end{tabular}

with or without meniscal tear (Table 2).

There was moderate correlation between TSK and LKS
(Figure 1). The TAS had significant and inverse correlation with TSK (Figure 2). Higher TSK led to lower TAS and vice versa. (Table 3) (Figure3).

Table 2. Distributions of socio-demographic and treatment characteristics of groups. The table shows correlation between TSK, TAS and LKS. KT1000 arthrometer Knee Score of operated and non-operated knees are given in this table.

\begin{tabular}{|c|c|c|c|c|}
\hline & $\begin{array}{c}\text { Total } \\
(n=50)\end{array}$ & $\begin{array}{l}\text { Non-Meniscal Tear } \\
\qquad(n=30)\end{array}$ & Meniscal Tears $(n=20)$ & $\mathbf{p}$ \\
\hline Postop Tempa Kinesiophobia Score & $35,8 \pm 13,2$ & $31.6 \pm 8.85$ & $42.1 \pm 16.14$ & 0.013 \\
\hline Postop Tegner Activity Score & $6,76 \pm 2,85$ & $7.37 \pm 2.4$ & $5.85 \pm 3.27$ & 0.084 \\
\hline Lysholm KNee Score & $92,3 \pm 5,99$ & $93.67 \pm 5.86$ & $90.25 \pm 5.73$ & 0.047 \\
\hline OPKT100015P & $4,49 \pm 1,42$ & $4.57 \pm 1.38$ & $4.37 \pm 1.5$ & 0.638 \\
\hline OPKT100020P & $6,16 \pm 1,57$ & $6.13 \pm 1.46$ & $6.21 \pm 1.78$ & 0.875 \\
\hline OPKT100030P & $8,1 \pm 1,85$ & $7.87 \pm 1.7$ & $8.47 \pm 2.06$ & 0.268 \\
\hline NPKT100015P & $3,53 \pm 1,32$ & $3.7 \pm 1.26$ & $3.26 \pm 1.41$ & 0.265 \\
\hline NPKT100020P & $4,8 \pm 1,55$ & $5.03 \pm 1.45$ & $4.42 \pm 1.68$ & 0.182 \\
\hline NPKT100030P & $6,33 \pm 1,95$ & $6.7 \pm 2$ & $5.74 \pm 1.76$ & 0.093 \\
\hline
\end{tabular}

Table 3. Pearson's correlation coefficients between Lysholm knee score (LKS) and Tampa scale of Kinesiophobia (TSK) and with Tagner Activity score(TAS). It shows the correlation between LKS and TAS postoperatively

\begin{tabular}{|l|c|c|c|}
\hline & \multicolumn{2}{|c|}{ Postop Tempa Kinesio-phobia Score } & \multicolumn{2}{c|}{ Postop Tegner Activity Score } & $\mathbf{p}$ & $\mathbf{p}$ & $\mathbf{p}$ & 0.517 \\
\hline Lysholm Knee Score & $\mathbf{r}$ & $<0.001$ & $<0.001$ \\
\hline Postop Tegner Aktivity Score & -0.530 & $<0.001$ & \\
\hline r: Pearson's Correlation coefficient & -0.897 & \\
\hline
\end{tabular}




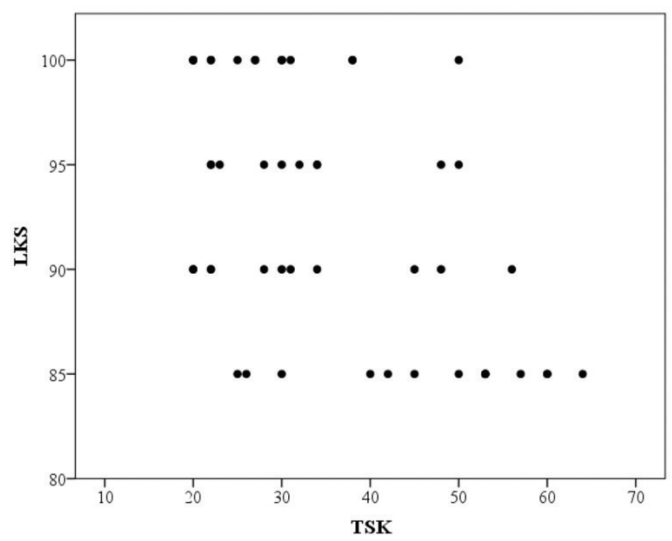

Figure 1. Scatter plot between LKS and TKS

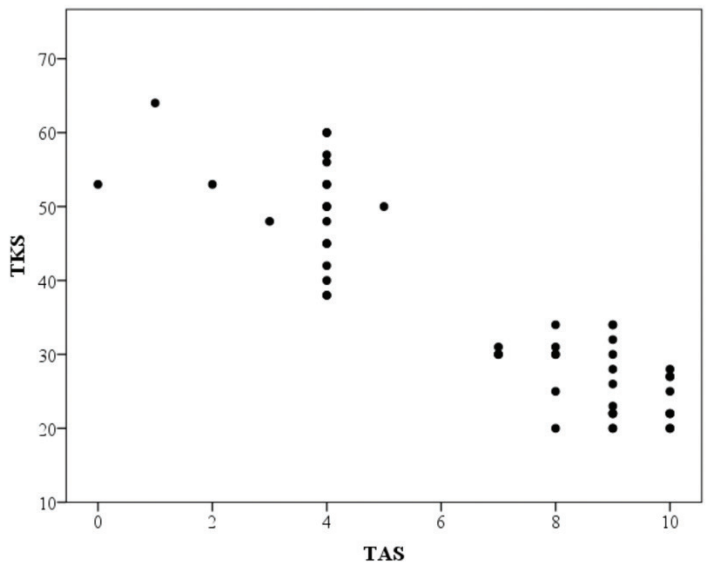

Figure 2. Scatter plot between TKS and TAS

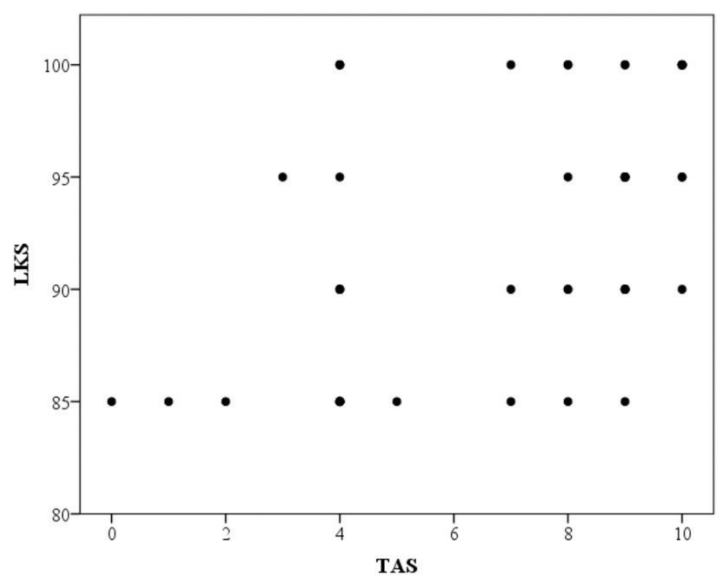

Figure 3. Scatter plot between LKS and TAS

\section{DISCUSSION}

Probably the most important aspect of the current study was to emphasise the role of kinesio-phobia in returning sportive and daily activity after ACLR. The aim of ACLR surgery is to stabilize the knee joint, to prevent further injuries and to allow patients return to their previous level of activ-ity. Rehabilitation helps to restore range of motion, strengthen the muscles and improve knee functions. ${ }^{5}$ However, most patients with ACL reconstruction do not return to their preinjury activity levels..$^{13,14,15}$ Despite recent improvements in surgical and rehabilitation techniques to restore knee function, it was reported that $20-50 \%$ of ACLR patients do not return to the same sport activity level after the surgery. ${ }^{13,14,15,16}$ Physical therapy is not the only benchmark for surgical success but psychological factors are also as important. Several factors play roles in returning pre-injury activi-ties. Some authors are proponents of a delayed return to sport until specific strength and function goals are met. ${ }^{17,18}$ Social factors such as job changes or childbirth may also cause patients to re-duce activity levels. ${ }^{14}$ In a review of psychological predictors of outcome, a consistent relationship was demonstrated between a patient's self-confidence, optimism and motivation to recover from injury, and the actual outcome of the surgery. ${ }^{12,19}$ In order to optimize rehabilitation outcomes, it is also important to understand the psychological aspect of the patients after an injury and during the rehabilitation process. ${ }^{20}$ One of the psychological factors is fear of reinjury or kinesiophobia and it may play a significant role in some patient's inability to successfully return to their previous level of sports participation. ${ }^{20}$

In the current study, higher kinesiophobia scores led to low activity scores (TAS). This might mean that participation to daily and sport activities is not fully related to the knee function but could be related to fear of re-injury, stress or psychological block. In return, those factors might create feel-ings of uncertainty and also fear of how far the injury will affect future function. ${ }^{21}$ Additionally, these feelings can cause the individual's negative attitudes toward 
the body and participating in daily activities and sports. Catastrophizing pain and fear of pain is a major cause of delayed re-covery and discharge after musculoskeletal injury and surgery according to some articles. ${ }^{22,23,24}$ George et al. also highlighted that a physiotherapist should identify people with a continued high kinesiophobia level and then address it. Many studies emphasize that psychological responses to the initial injury, to surgery, to recovery and rehabilitation might be an important additional deter-minant of reintegration into usual activities and returning to sport after the surgery. ${ }^{25}$ In our study, the patients who had high kinesiophobia before operation had high fear of pain and high kinesio-phobia postoperatively.

Kvist et al. reported that only 53\% of their patients returned to their pre-injury level of activity at 3 to 4 years after ACL reconstruction. They used the Tampa Scale of Kinesiophobia (TSK) by aim-ing at quantifying fear of re-injury due to movement and physical activity to evaluate their patients. They found that the patients who did not return to pre-injury levels scored higher on TSK, which meant that they had greater fear of pain, or re-injury and this was correlated to low knee-related quality of life. ${ }^{12}$ In the current study, the patient who had high rate of TSK had low rate of TAS. Despite this, they had high rate of LKS. Additionally, there was no correlation between TSK and LKS.

In current study, age was also an important factor in outcome and the age $>40$ had positive corre-lation with the TSK and inverse correlation with TAS and LKS. The younger patients have high score of TAS and LKS and low score of LKS. They were more likely to return their pre-injury sport activities. Teenagers and young adults are less likely to encounter many of the life-related events, such as childbirth, increased job demands, and marriage; therefore, a younger patient may have a greater potential for returning to sport than an older patient of equivalent knee health and over-all fitness. Older patients may be less motivated by intrinsic factors such as athletic self- identi-ty. ${ }^{26,27,28}$ In a prospective study by Brewer et al., high levels of athletic self-identity strongly predict-ed rehabilitation compliance in younger patients (mean age, 18 years) but had essentially no rela-tion to compliance rates among older patients (mean age, 30 years). ${ }^{28}$

In a pilot study of Ana Tichonova et al, they claim that a high level of kinesiophobia was signifi-cantly correlated with experience of more difficulties in daily activities and poorer knee-related quality of life before and after rehabilitation. ${ }^{11}$ Our study also showed that high rate of kinesio-phobia effects the daily activities and sportive activities but was not correlated with knee function. The postoperative LKS with both high and low kinesiophobia rates was significantly high.

Gobbi et al. found that there were no significant differences when using various knee outcome scores between athletes who "returned" to their pre-injury sport level (65\%) and those who did not return. This meant that for their cohort, knee outcome instruments like LKS was not able to predict return to sports post-ACL reconstruction. The authors suggested the use of Marx knee activity rating and evaluation of the athlete's psychological profile as additional scales to determine which patients have a greater chance of returning to their pre-injury levels. ${ }^{29}$ In our study, LKS was also high for both patients' groups with both high and low TSK. The patients with high TSK score had lower TAS and vice versa. There was no correlation between TSK and LKS. Therefore, the knee outcome instrument may not be able to predict return to sport.

Psychological factors also effect patients' return to preinjury activity. In another review of patients with minimum 5-year follow-up by Dave YH Lee et al. also indicated that fear of re-injury is an im-portant psychological factor for these patients not returning to sports. They also suggested that the surgeon to counsel the ACL deficient patient, who has been considered for surgical recon-struction, about the likelihood of an eventual return to sports. ${ }^{14}$ 
In ACL-deficient patients without gross knee instability, it may be useful to identify those who are at increased risk for not returning to sport after surgical intervention. A psychological screening approach may eventually be feasible because several recent studies in the ACL rehabilitation literature indicate that psychological screening can be predictive of patient outcomes. ${ }^{12,14,30}$ In par-ticular, preoperative or early postoperative screening can be performed for factors such as level of self-motivation, depression, and even personality traits that are associated with future rehabilita-tion compliance rates, post-rehabilitation pain scores, higher levels of pain, and return to sport although baseline psychological factors do not appear to be predictive of short-term outcomes in the early rehabilitation phase. Determining the patients with high kinesiophobia is important, in order to optimize and improve rehabilitation outcomes and also, it is important to understand the psychological aspect of the patients after an injury during the rehabilitation process and after sur-gery. ${ }^{31}$ We suggest that the patients determined with high kinesiophobia preoperatively should have a psychotherapy for kinesiophobia in addition to their physical therapy.

Westermann et al. reported that meniscal repair failure rate was $14 \%$ in their six-year follow-up study with concurrent meniscal repair and ACL reconstruction patients. They also reported that there was no difference in the suture number or type when assessing repair success and failure. $^{32}$

In addition, Uzun E. et al reported that there was not any superiority of meniscal tear in outcome of patients with ACL reconstruction. ${ }^{33}$ In our study, we also did not find any differences of ACLR patients with or without meniscal repair.

\section{CONCLUSION}

Our study showed that good knee function is not the only indicator to return preinjury daily and sport activities but kinesiophobia may also play a significant role even if the Lyshman knee score is higher. Therefore, The patients with ACL injury should be informed about the kinesiophobia. We advise that a kinesiophobia test could be added to the patients' assessment who had ACL injury. The patients who have high rate of kinesiophobia preoperatively, may benefit from psychotherapy postoperatively in addition to their physical therapy.

\section{Limitations}

This study had limitations, such as some patients did not only have ACLR, but also had additional meniscal repair. The small sample size might also be a limit for generalisation of the findings.

\section{Conflict of interest}

The authors reported no conflict of interest for this study. 
Sakarya Med J 2019;9(2):289-296

KOCHAI et al. Kinesiophobia Following ACL

\section{References}

1. Baer GS, Harner CD. Clinical outcomes of allograft versus autograft in anterior cruciate lig-ament reconstruction. Clin Sports Med 2007; 26:661-681.

2. National Center for Health Statistics (NCHS). Vital and health statistics: ambulatory and in-patient procedures in the United States, 1996. Washington, DC: Centers for Disease Control and Prevention; 1998

3. Griffin LY, Agel J, Albohm MJ, Arendt EA, Dick RW, Garrett WE, et al. Noncontact anterior cruciate ligament injuries: risk factors and prevention strategies. J Am Acad Orthop Surg 2000; 8(3): 141-50.

4. Marx RG, Jones EC, Angel M, Wickiewicz TL, Warren RF. Beliefs and attitudes of members of the American Academy of Orthopaedic Surgeons regarding the treatment of anterior cruciate ligament injury. Arthroscopy 2003; 19:762-770. [PubMed: 12966385]

5. Vlaeyen J W, Kole-Snijders A M, Boeren R G, van Eek H. Fear of movement/ (re)injury in chronic low back pain and its relation to behavioral perfor-mance. Pain 1995b; 62 (3): 363-72.

6. Wilk KE, Macrina LC, Cain EL, Dugas JR, Andrews JR. Recent advances in the rehabilita-tion of anterior cruciate ligament injuries. Orthop Sports Phys Ther 2012;42(March (3)):153-71.

7. Butler DL, Noyes FR, Grood ES. Ligamentous restraints to anterior-posterior drawer in the human knee: a biomechanical study. J Bone Joint Surg [Am] 1980; 62-A:259-270.

8. Kiapour A.M. and Murray M.M., Basic science of anterior cruciate ligament injury and Bone Joint Res $2014 \mathrm{Feb}$; 3(2):20-31.

9. Kori SH, Miller RP, Todd DD. Kinesiophobia: A new view of chronic pain behavior. Pain Manag 1990;3:35-43.

10. Laeyen JW, KoleSnijders AM, Rotteveel AM, Ruesink R, Heuts PH. The role of fear of movement (re)injury in pain disability. J Occup Rehabil 1995;5(4):235-52.

11. Ana Tichonova, Inesa Rimdeikiené, Daiva Petruševičienè, Eglè Lendraitiené. The relation-ship between pain catastrophizing, kinesiophobia and subjective knee function during re-habilitation following anterior cruciate ligament reconstruction and meniscectomy: A pilot study. Medicina 52 (2016) 229-237

12. Kvist J, Ek A, Sporrstedt K, Good L. Fear of re-injury: a hindrance for returning to sports after anterior cruciate ligament reconstruction. Knee Surg Sports Traumatol Arthrosc 2005;13(July (5)):393-7.

13. Everhart JS, Best TM, Flanigan DC. Psychological predictors of anterior cruciate ligament reconstruction outcomes: a systematic review. Knee Surg Sports Traumatol Arthrosc 2015 Mar;23(3):752-62. doi: 10.1007/s00167-013-2699-1

14. Lee DY, Karim SA, Chang HC. Return to sports after anterior cruciate ligament reconstruc-tion. A review of patients with minimum 5-year follow-up. Ann Acad Med Singapore 2008; 37:273-278.

15. Ardern CL, Taylor NF, Feller JA, Webster KE. Return-to-sport outcomes at 2 to 7 years after anterior cruciate ligament reconstruction surgery. Am J Sports Med 2012; 40(1): 41-8.

16. Ardern CL, Webster KE, Taylor NF, Feller JA. Return to the preinjury level of competitive sport after anterior cruciate ligament reconstruction surgery: two-thirds of patients have not returned by 12 months after surgery. Am J Sports Med 2011; 39(3): 538-43.

17. Aglietti P, Giron F, Buzzi R, Biddau F, Sasso F. Anterior cruciate ligament reconstruction: bone-patellar tendon-bone compared with double semitendinosus and gracilis tendon grafts. A prospective, randomized clinical trial. J Bone Joint Surg Am 2004; 86-A (10): 214355 .
18. Barber-Westin SD, Noyes FR. Factors used to determine return to unrestricted sports activ- $i$ ties after anterior 30. cruciate ligament reconstruction. Arthroscopy 2011;27: 1697-1705.

19. Thomee R, Kaplan Y, Kvist J, et al. Muscle strength and hop performance criteria prior to return to sports after ACL reconstruction. Knee Surg Sports Traumatol Arthrosc 2011;19:1798-1805.

20. Flanigan DC, Everhart JS, Pedroza A, Smith T, Kaeding CC. Fear of reinjury (kinesio-phobia) and persistent knee symptoms are common factors for lack of return to sport after anterior cruciate ligament reconstruction. Arthroscop. 2013;29(8):1322-9.

21. Michael j. Medvecky, Stephen Nelson. Kinesiophobia and Return to Sports After Anterior Cruciate Ligament Reconstruction. Connecticut Medicine March 2015, Volume 79, NO. 3

22. Österberg A, Kvist J, Dahlgren MA. Ways of experiencing participation and factors affect-ing the activity level after nonreconstructed anteriorcruciate ligament injury: a qualitative study. J Orthop Sports Phys Ther 2013;43(March (3)):172-83.

23. Leeuw M, Goossens ME, Linton SJ, Crombez G, Boersma K, Vlaeyen JW. The fear-avoidance model of musculoskeletal pain: current state of scientific evidence. J Behav Med 2007;30(February (1)):77-94.

24. Quartana PJ, Campbell CM, Edwards RR. Pain catastrophizing: a critical review. Expert Rev Neurother 2009;9(May (5)):745-58.

25. George SZ, Lentz TA, Zeppieri G, Lee D, Chmielewski TL. Analysis of shortened versions of the tampa scale for kinesiophobia and pain catastrophizing scale for patients after ante-rior cruciate ligament reconstruction. Clin J Pain 2012;28(January (1)):73-80.

26. Ardern CL, Webster KE, Taylor NF, Feller JA. Return to sport following anterior cruciate lig-ament reconstruction surgery: a systematic review and meta-analysis of the state of play. Br J Sports Med 2011;45(June (7)):596-606.

27. Ardern CL, Taylor NF, Feller JA, Webster KE. Fifty-five per cent return to competitive sport following anterior cruciate ligament reconstruction surgery: an updated systematic review and meta-analysis including aspects of physical functioning and contextual factors. $\mathrm{Br} J$ Sports Med 2014;48 (November (21)):1543-52.

28. Brewer BW, Cornelius AE, Van Raalte JL, et al. Age related differences in predictors of adherence to rehabilitation after anterior cruciate ligament reconstruction. J Athl Train 2003;38:158-162.

29. Gobbi A, Franscisso R.(2006). Factors affecting return to sports after anterior 332 cruciate ligament reconstruction with patellar and hamstring graft: a prospective clini-333 cal inves-tigation. Knee Surg Sports Traumatol Arthrosc 14(10):1021-8.

30. Brewer BW, Van Raalte JL, Cornelius AE, et al. Psychological factors, rehabilitation ad-herence, and rehabilitation outcome after anterior cruciate ligament reconstruction. Reha-bilitation" Psychology $2000 \mathrm{Feb}$ 45(1):20-37

31. Thomeé P, Währborg P, Börjesson M, Thomeé R, Eriksson BI, Karlsson J. Self-efficacy of knee function as a pre-operative predictor of outcome 1 year after anterior cruciate liga-ment reconstruction. Knee Surg Sports Traumatol Arthrosc 2008;16:118-127.

32. Westermann RW, Wright RW, Spindler KP, Huston LJ, MOON Knee Group, Wolf BR. Me-niscal repair with concurrent anterior cruciate ligament reconstruction:operative success and patient outcomes at 6-year follow-up. Am J Sports Med 2014;42(9):2184-92.

33. Erdal Uzun, Abdulhamit Misir, Turan Bilge Kizkapan, Mustafa Ozcamdalli, , Soner Akkurt, Ahmet Guney. Arthroscopic medial meniscal repair with or without concurrent anterior cru-ciate ligament reconstruction:A subgroup analysis. The knee volume 25, Issue 1,109117. Doi 10.1016/j.knee.2017.11.003 